\title{
Application for Membership
}

\section{The Fauna Preservation Society}

c o The Zoological Society of London, Regent's Park, London NW1

Please enrol me as a member of the Society

Name (BLOCK LETTERS) Please state Mr/Mrs/Miss or title

\section{Address}

I enclose $£$ : :

being my subscription as a Life/Benefactor/Ordinary Member.

The minimum subscription for Ordinary Members is £3, US \$7.75, for Benefactors £10, US \$25, payable on January 1st. A Banker's Order saves time, expense and reminders. The value of any subscription is greatly increased if it is paid under a seven-year Deed of Covenant (UK standard-rate income taxpayers only) and this entails no extra cost whatever: write for Covenant forms to the Secretary.

Llfe membership fees:

Age: Under 41, £200, US \$485; age 41-60, £150, US \$365; age 61 and over, $£ 75$ US $\$ 185$.

\section{Banker's Order}

\section{Bank}

Address of Bank

Please pay for the Credit of The Fauna Preservation Society, Barclays Bank Ltd., Camden Town, London NW1, my subscription of $£ \ldots . .$. due on 1 st January, 19 , and a simllar amount on 18 t January each year until further notice. 


\section{THE TRYON \\ GALLER Y \\ 41/42 DOVER STREET, LONDON W.1. \\ (01-493-1561)}

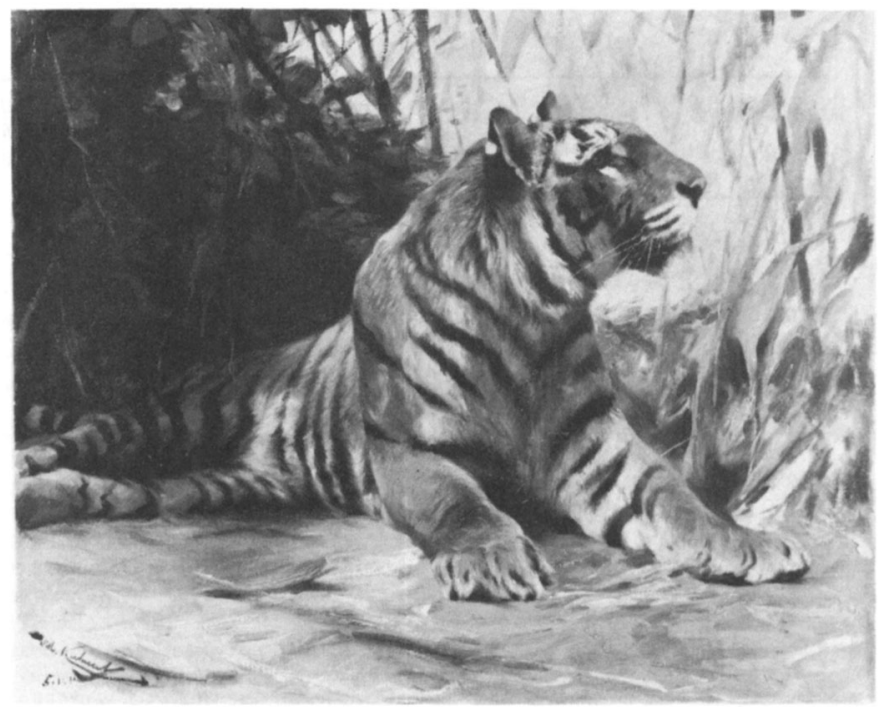

WILHELM KUHNERT

We wish to purchase pictures by Richard Friese, Carl Rungius, Wilhelm Kuhnert and Gerhard Lobenberg. 


\section{THE MOORLAND GALLERY}

23 CORK STREET, BOND STREET LONDON W.1.

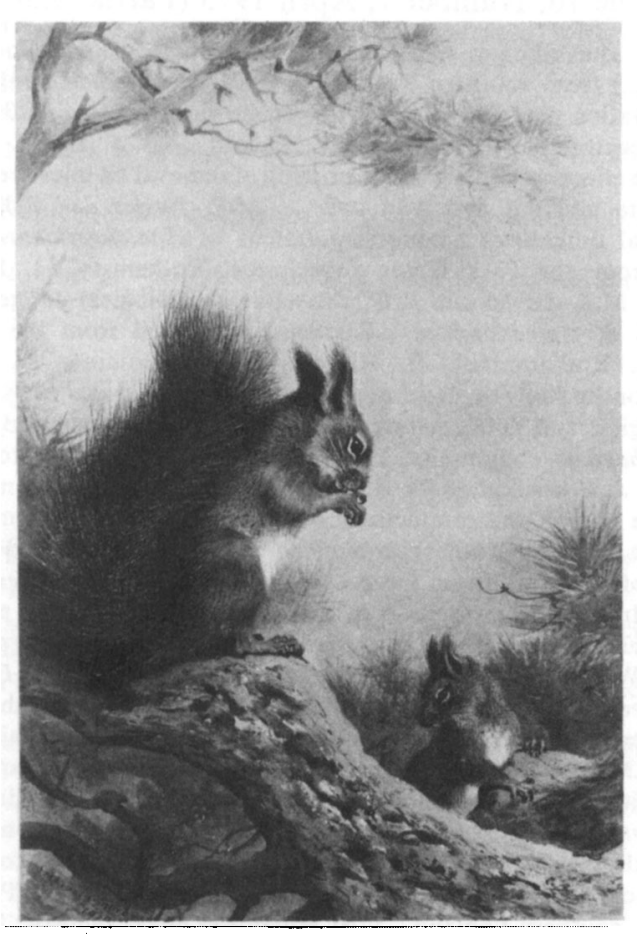

ARCHIBALD THORBURN

We wish to purchase pictures by Archibald Thorburn, George Lodge,

Frank Wallace and Joseph Wolf. 


\title{
Journal of Applied Ecology
}

\author{
Edited by \\ T.H. Coaker and H.W. Woolhouse
}

\section{Volume 10, Number 1, April 1973 (Partial Contents)}

R. Knight: The climatic adaption of populations of cocksfoot (Dactylis glomerata L.) from southern France D.R. McQueen: Changes in under storey vegetation and fine root quantity following thinning of 30-year Pinus radiata in central North Island, New Zealand K.A. Haizel and John L. Harper: The effects of density and the timing of removal on interference between barley, white mustard and wild oats M.S. Davies and R.W. Snaydon: Physiological differences among populations of Anthoxanthum odoratum $\mathbf{L}$. collected from the Park Grass Experiment, Rothamsted. I. Response to calcium M.S. Davies and R.W. Snaydon: Physiological differences among populations of Anthoxanthum odoratum L. collected from the Park Grass Experiment, Rothampsted. II. Response to aluminium J. Grace: An apparatus for the study of leaf canopy optics J. Grace and $H . W$. Woolhouse: A physiological and mathematical study of the growth and productivity of a Calluna-Sphagnum community. II. Light interception and photosynthesis in Calluna J. Grace and H.W. Woolhouse: A physiological and mathematical study of the growth and productivity of a Calluna-Sphagnum community. III. Distribution of photosynthate in Calluna vulgaris L. Hull M.J. Robson: The effect of temperature on the growth of $\mathbf{S . 1 7 0}$ tall fescue (Festuca arundinacea). II. Independent variation of day and night temperature effects $R$. Elfyn Hughes: Studies in sheep population and environment in the mountains of north-west Wales. Introduction R. Elfyn Hughes, J. Dale, I. Ellis Williams and D.I. Rees: Studies in sheep population and environment in the mountains of north-west Wales. I. The status of the sheep in the mountains of north Wales since Mediaeval times H.A. Roberts and Patricia M. Feast: Emergence and longevity of seeds of annual weeds in cultivated and undisturbed soil $T$.W. Hegarty: Effects of total solar radiation and temperature on vegetative growth in the east of Scotland Roderick Hunt: A method of estimating root efficiency Lena $K$. Ward : The conservation of juniper. I. Present status of juniper in southern England $\quad N$. Waloff and M.G. Soloman: Leafhoppers (Auchenorrhyncha: Homoptera) of acidic grassland B.N.K. Davis: The Hemiptera and Cleoptera of stinging nettle (Urtica dioica L.) in East Anglia

The Journal of Applied Ecology is published three times a year at $£ 5.25$ $(\$ 17.00)$ per issue; subscription price $£ 14.00(\$ 47.00)$ per annum, post free. New subscriptions and requests for specimen copies should be addressed to Blackwell Scientific Publications Ltd, Osney Mead, Oxford OX2 OEL

\section{Blackwell Scientific Publications}




\title{
Mammal Review
}

\section{Edited by John Clevedon Brown and Michael N. Dadd}

Published quarterly at $\mathbf{f 6 . 0 0}(\$ 20.00)$ per annum, post free

Recent issues already published or in production include:

Volume 2, Number 1. The ecology of small rodents in tropical Africa $M . J$. Delany

Volume 2, Number 2. Possible health hazards associated with the collection and handling of post-mortem zoological material $A$. D. Irvin, J. E. Cooper and S.R. Hedges

The National Badger Survey Ernest Neal

Volume 2, Number 3. A review of mammalian age determination methods P. Morris

Volume 2, Number 4. Radioactive marking of small mammals G.N.A. Bailey, I. J. Linn and P. J. Walker

Volume 3, Number 1. The rodent preputial gland J. Cleveland Brown and J. D. Williams

\section{East African Wildlife Journal}

\author{
Edited by J. B. Sale
}

Published quarterly at $\mathbf{\AA 8 . 0 0}(\$ 27.00)$ per annum, post free

Contents of Volume 10, Number 3:

Population structure of olive baboons (Papio anubis (J. P. Fischer)) in the Laikipia District of Kenya Michael E. Berger

Defaecation by African elephants (Loxodonta africana (Blumenbach)) Malcolm Coe

An investigation of some sources of bias in aerial transect sampling of large mammal populations C. J. Pennycuick and D. Western

The use of drinking sites, wallows and salt licks by herbivores in the flooded Middle Zambezi Valley P. J. Jarman

The aardwolf (Proteles cristatus Sparrman-1783) as predator of termites H. Kruuk and W. A. Sands

Mineral content of elephant dung $J$. S. Weir

Observations on endoparasites of some East African vertebrates $M$. A. Pierce

Home range, movements and food of a buffalo herd in Tsavo National Park Walter Leuthold

Birds of the Cherangani Montane forests and their parasites $R$. A. Cheke

Subscriptions to either of these journals should be accompanied by the appropriate remittance and sent to Blackwell Scientific Publications Ltd., Osney Mead, Oxford OX2 0EL, England.

\section{Blackwell Scientific Publications}




\section{3/74 Special Interest Tours by PEREGRINE HOLIDAYS}

\section{TURKEY - Autumn - EASTERN ANATOLIAN ADVENTURE}

Now has an extra day at Lake Van and the 4 days here and 3 days on horseback in the village of the Pontic Alps over Xenophon's route make this tour unique of its kind. Visits all the major sites en route to Trebizond including Ancient Ani and Palace of Ishak Pasha. Dr. Anthony Bryer will illumine and entertain as before with en route and on site talks. Occurs at time of maximum North to South migration of raptors in particular.

Depart 22 August 16 days $£ 260.00$

\section{SEYCHELLES - Summer - NATURAL HISTORY STUDY TOUR}

Specially prepared tour for University College, Cardiff now has a few places open for the general public. An unusual opportunity to extend or even begin an interest in nature with particularly compatible companions. Guest Lecturers. Dr. Mary Gilham, Senior Staff Tutor Biological Sciences. David White, M.Sc. of the Nature Conservancy.

Depart 21 July 24 days $\$ 350.00$

\section{GALAPAGOS - QUITO - UPPER AMAZON Summer 1974 NATURAL HISTORY}

Air to QUITO; High Andes to Pacific Coast by one of the world's most exciting rail journeys; 11 days cruise to Darwin's GALAPAGOS with landings on all the islands of major interest, on board a well-appointed cruise ship refitted 1972 and specially chartered; sightseeing, bird watching, flower hunting around QUITO; finally a superb 4-5 day river and jungle expedition on the AMAZON. Unlimited optional extensions (e.g. Giant Trout fishing - up to 12 lbs.; Deep Sea Fishing - sailfish, swordfish, marlin, some of the best in the world; to Machu Picchu, Lake Titicaca and other sites). Three or four internationally famous guest lecturers for birds, flowers and zoology.

Depart 1 August 1974. 21 days $\$ 575.00$ (Includes donation to Darwin Research Station Galapagos.)

\section{INDIA \& NEPAL - Spring 1974 - BIRDS \& LARGE MAMMALS}

Delhi, Agra, Fatipur Sikri, Kathmandu, Bharatpur, Corbett and Kaziranga National Parks. John Gooders B.Sc. (guest Lecturer) who planned this tour after a recent visit* says " we shall try to see our 300 birds species and many large animals (one-horned rhino, tiger, etc., which often remain unseen) along with superb flowers and butterflies." At Bharatpur accommodation is in a Maharajah's Palace and in Nepal you will ride through the jungle on elephants to stay at romantic Tiger Tops Jungle Lodge. Accompanied by Sue Gooders (photography) Patricia Hodgekins (Admin.)

* a month gaining material and experience for a "SURVIVAL" TV programme Depart 16 February 1974. 20 days. $£ 460.00$

All by Scheduled Air Services and fully inclusive.

Detailed brochures from

Peregrine Holidays at Town and Gown Travel, 41 South Parade, Summertown, Oxford.

Tel. Oxford (0865) 54517 and 55345.

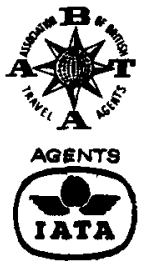




\section{SWANS BIG GAME \& BIRDS SAFARIS}

\section{VISITING THESE NATIONAL PARKS \& GAME RESERVES}

Nairobi, Lakes Naivasha and Nakuru, Samburu, Tsavo, Lake Manyara, Ngorongoro, Serengeti, and Mara in Kenya \& Tanzania.

\section{DAYS $\& 452$}

\section{GUEST LEGTURERS}

accompany each Safari and their expert and personal knowledge of East Africa its animals and birds, its history, peoples and customs highlight your enjoyment. DEPARTURES

June 27; July 18; Aug. 8, 29 ; Sept. 19; Oct. 10, 31 .

\section{BEAGH AND TREE-TOP} SAFARIS

A great opportunity to combine the thrill of seeing East African wildlife with the enjoyment of beautiful beaches.

21 days from $£ 260$

\section{SWANS HELLENIC CRUISES}

See the archaeological and architectural masterpieces of ancient lands and enjoy the pleasure of cruising to them on a well-found ship-to

\section{GREEGE, TURKEY,} SIGILY, CYPRUS \& THE MIDDLE EAST
All cruises are arranged in conjunction with the HEL. LENic Thayellens OLUB and excursions are made ten times more fascinating by a team of historical, archaeological and botanical experts including Sir Mortimer Wheeler, Sir John Wolfenden and others.
YOU FLY FROM LONDON to Venice, Naples or Athens-cruise-and return from Venice, Naples or Athens. Three cruises in May/June and three in August/September. Prices range from

$\$ 144$ to $\mathbf{2 4 2 7}$

including shore excursions

\section{SWANS ART TREASURES TOURS OF INDIA}

with KASHMIR, MEPAL \& SIKKIM

Visiting Srinagar, Pahalgam, Gulmarg, Delhi, Agra, Kathmandu, Patan, Bhadgaon, Tiger Tops, Darjeeling, Gangtok.

\section{2 days 2385}

\author{
with GEYLOK \\ Visiting Delhi, Agra, Fateh- \\ pur Sikri, Sikandra, Banaras, \\ Sarnath, Bhubaneswar, Puri, \\ Konarak, Hyderabad, Ban- \\ galore, Mysore, Somnath- \\ pur, Belur, Halebid, Madras, \\ Kanchipuram, Mahabalipur- \\ am, Colombo, Kandy, Polo- \\ nnaruwa, Sigiriya, Mihintale \\ Anuradhapura. \\ 25 days $\mathbf{\$ 4 6 5}$
}

\section{with NEPAL \& SIKKIM}

Visiting Bombay, Udaipur, Jaipur, Amber, Delhi, Agra, Fatehpur Sikri, Sikandra, Khajuraho, Banaras, Sarnath, Kathmandu, Patan, Bhadgaon, Darjeeling, Gangtok.

\section{4 days $\mathbf{2 4 7 0}$}

Each Tour is accompanied by a Guest Lecturer whose personal knowledge of this fascinating and colourful sub-continent will bring to life much of its historic past.

DEPARTURES: Sept. 15 ; Oct. 6, 27 ; Nov, 15.

Above are five Swans Specialised Cruises and Tours, in addition there are the following;

Tours of Great Houses and Gardens in England \& Wales.

Art Treasures Tours of Italy and Southern Italy; Sicily; Central

Asia \& Transcaucasia; Persia; Far East; Leon \& Castile; Moscow \& Leningrad.

Archaeological Tours of Sicily; Mexico \& Guatemala; Roman Britain.

Special Interest Tours of The Holy Land; Morocco; Ethiopia.

600-mile Nile Cruise.

Special brochures on all Swans Specialised Cruises and Tours from:

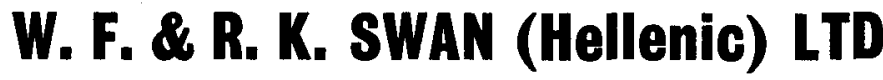

237 (227) Tottenham Gourt Road, London W1P OAL Tel. 01-636 8070 


\section{Zasmbia}
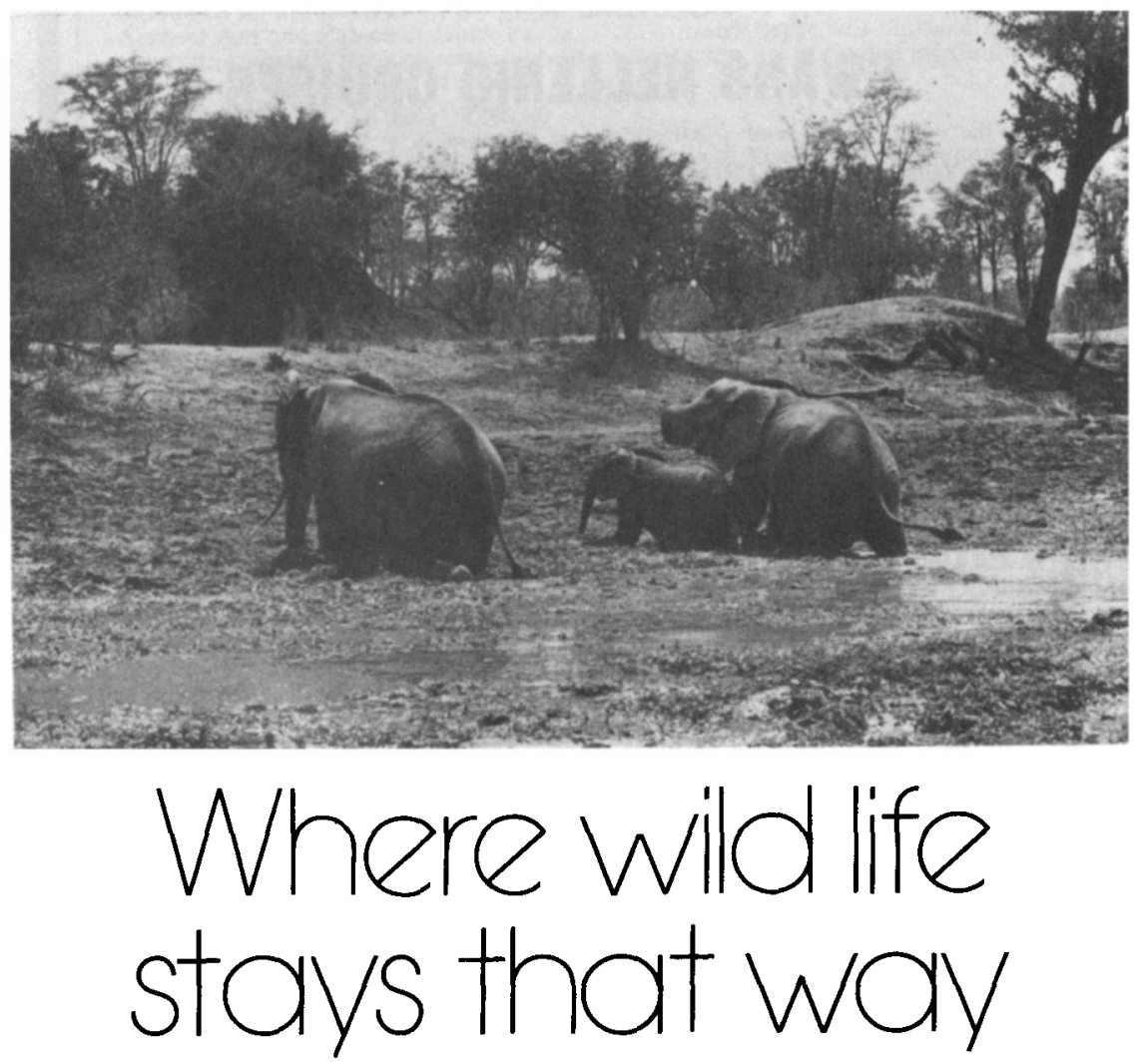

Nowhere else in Africa is conservation taken so seriously as in Zambia. To us, conservation means protecting our fauna from that most dangerous of predators-man-whilst preserving their natural habitat and maintaining the ecological balance.

Zambian wild life is completely free, uniquely unspoilt, staggeringly profuse and diverse. The vast game parks which keep it that way are a naturalist's paradise.

Come and see them.

ZAMBIA NATIONAL tOURIST BUREAU 163 Piccadilly, London W.1. Tel: 01-4935552 


\section{Birdwatcher's Paradise}

\section{Ornithological Tours of Kenya.}

Explore the equatorial alpine moorlands of Mount Kenya for brilliant Sunbirds. Find Lily-trotters among the papyrus and blue water lilies of Lake Naivasha. Visit the Ark at night and hope to catch a glimpse of the rare and elusive Bongo amongst other animals at the waterhole. Visit a Masai warriors' village and witness war dances beneath giant acacias, still typical of unspoilt Africa.

All this accompanied by an expert on East African wildlife. Scheduled return jet flight London-Nairobi. Guaranteed window seat when in safari vehicle. Accommodation in excellent hotels and wild life lodges.

\section{$£ 425$ for 16 days.}

\section{Simba Travel,}

(Ref. 0), 4 St. Agness Well, Old Street Station, London EC1. 01-253 3525
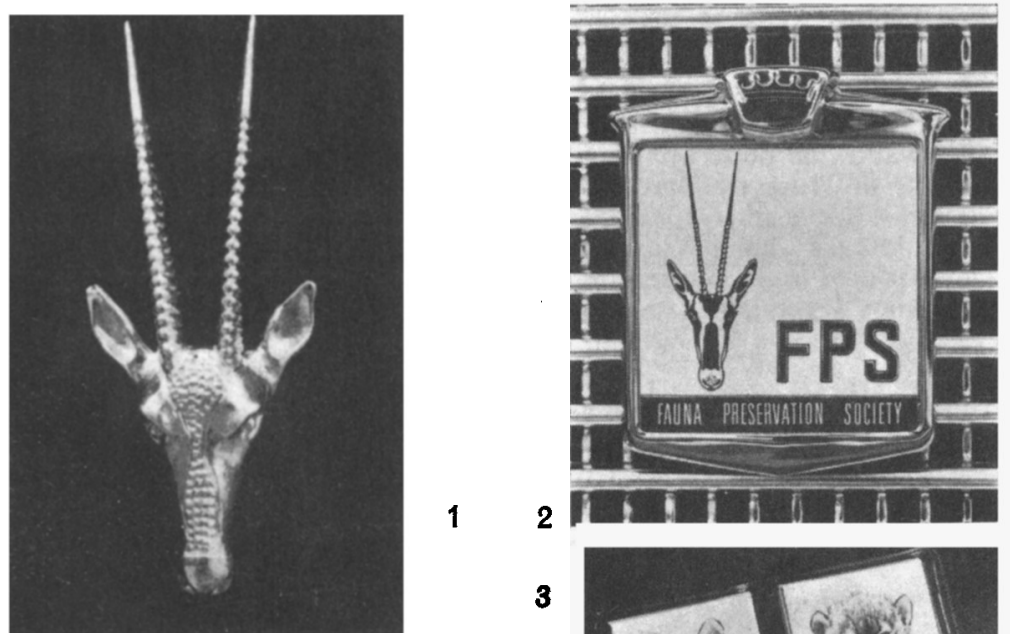

1. Oryx brooch in gold $£ 9.75$, or silver $£ 4.55$ 2. Car badge in midnight blue, cream, chrome and black. For grill and badge bar £1.55. 3. FPS notelets - Ralph Thompson drawings, ten in wallet (five of each design) with envelopes $35 p$.

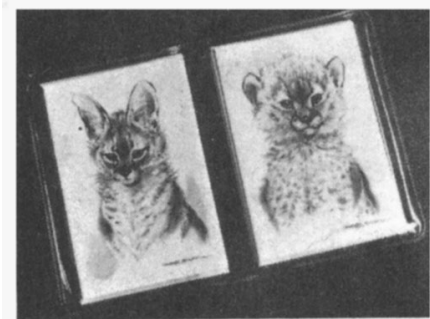

other Gifts obtainable from the FPS Office 


\section{FPS Wildlife Film Library}

Unless otherwise stated all films are $16 \mathrm{~mm}$. in colour with sound track and cost $£ 1$ each to hire. To book a film please write to the Films Officer, Fauna Preservation Society, c/o Zoological Society, Regent's Park, London NW1 4RY. Tel: 015860872.

The Peace Game-The wildlife of South Africa. South African Tourist Corporation. 25 mins. $£ 2$.

The Uganda Kob-Territorial and mating behaviour, by H. K. and J. H. Buechner. Presented by the Smithsonian Institution. 20 mins. $£ 2$.

The Last of the Wild, by Eugen Schuhmacher. 110 mins. $£ 10$.

Wildlife for the Future, by Gordon Maclean. 20 mins. £2. New film on work of a county naturalists' trust.

Saiga Saga. Life history and conservation of the saiga antelope, Russian commentary with English titles. 16 minutes. Presented by the Soviet Peace Committee. $£ 2$.

Koala, by H. J. Pollock. Complete life history. 24 minutes. $£ 2$.

Marloo, The Red Kangaroo, by H. J. Pollock. 25 minutes. £2.

The Seals of Macquarie Island. Elephant and fur seals. 12 minutes.

Penguins of Macquarie Island. King, gentoo, rockhopper and royal penguins. 13 minutes.

The Mallee Fowl. The remarkable nesting story of a 'mound-builder'. 11 minutes.

Le Aye Aye de Madagascar, by J. J. Petter. Black and white, French commentary, 22 minutes. Presented by the Service du Film de Recherche Scientifique.

The Silent Watcher, by Eric Ashby, commentary by Peter Scott. Badgers, dee and foxes in the New Forest. Black and white, 35 minutes. $£ 1.50$.

To Catch a Rhino. 20 minutes; South African Tourist Corporation.

The African Lion, by A. I. M. Hepburn. Taken in the Kruger National Park. Magnetic sound track. 12 minutes.

The Swallowtail Butterfiy. The complete life story. 25 minutes.

Wildlife in Trust, by Gordon Maclean. The work of a Naturalists' Trust (Berks, Bucks and Oxon). 25 minutes.

South Africa's Animal Kingdom. 20 minutes. S.A. Tourist Corp.

Down in the Forest. Kangaroos. 6 minutes. (For children).

Kaziranga Sanctuary, Assam. Two films, each 11 minutes; similar material.

\section{Silent Films with Captions}

Ceylon Wildlife, by C. E. Norris. Written commentary. 50 minutes.

Operation Oryx, by Michael Woodford. The FPS exepedition. Black and white, 30 minutes.

The African Elephant. 10 minutes. 


\section{Contents}

Page

Notes and Nows

FPS Tour to Botswana and Zambla

David Jenkins $\quad 15$

Oryx $100 \%$ Fund 18

IUCN General Assembly $\quad 20$

National Parks: a Conference Report 21

Protection in Surinam 23

The Lamal Wedge in Tanzania

John S. Owen $\quad 24$

Briefly. . .

Richard Fitter $\quad 25$

Spotted Cats in Latin America 37

The Swamp Deer in Kanha 40

Swamp Deer in Uttar Pradesh

Colin Holloway

Developments in the Sudan Parks

d. L. Cloudsley Thompson 49

Wildilife and Land Use in Scotland

James Lockie $\quad 53$

Pygmy Hog and Hispid Hare

Guy Mountfort $\quad 64$

The Yeti: No Snowman

J. A. McNeely, E. W. Cronin \& Howard B. Emery 65

Tunisia's Wildlife

R. G. M. Willan

74

The Persecuted Black Lechwe of Zambia

R. H. W. Bell and J. J. R. Grimsdell 77

Saving the Hawksbill Turtle

Robert Bustard $\quad 93$

Hartebeests in Ethiopia

Melvin Bolton

99

Saving the Tiger

Guy Mountfort

Colobus Monkeys and the Tourlst Trade

Russell A. Mittermeler 113

Book Revlews

Annual Report

Auditors' Report and Accounts 
Printed in Great Britain by

Alden \& Mowbray Led

at the Alden Press, Oxford 